\title{
Upper Cenomanian-Turonian two species of cyclostomaceous Bryozoa from the northern part of the Bohemian Cretaceous Basin, Czech Republic
}

Dva druhy cyklostomátních mechovek ze svrchního cenomanu turonu české křídové pánve, Česká republika

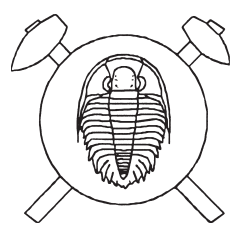

(4 figs)

HELENA ELIÁŠOVÁ

Mexická 5, 10100 Praha 10-Vršovice

The article presents a systematic description of two species of cyclostomatous Bryozoa: Tholopora(?) novaki (Gregory, 1909), age Upper Cenomanian to Lower Turonian, and a new species Radiopora soukupi sp. n. from sediments of the Upper Turonian age.

Key words: Bryozoa; Cyclostomata; Upper Cretaceous; Bohemian Cretaceous Basin; Czech Republic

\section{Introduction}

The samples described in this report were collected by Dr. Josef Soukup, Czech Geological Survey, Prague, and given to the present author for identification. The colonies of Tholopora(?) novaki (Gregory 1909) were collected at localities Plaňany $40 \mathrm{~km}$ east of Prague and from Netřeba and Korycany-Kopeč, $15 \mathrm{~km}$ north of Prague. The locality Plaňany represents a new exposure at the western edge of the quarry. The local fossiliferous rock is a Lower Turonian glauconitic sandstone containing sponges. Sediments at Netřeba and Korycany belong to the Upper Cenomanian. The colonies of Radiopora soukupi sp. n. have been found in the borehole J480751 at Chotovice, $70 \mathrm{~km}$ north of Prague, in Upper Turonian sediments.

The goal of this contribution is to record finds of interesting taxa of Bryozoa in sediments of the Bohemian Cretaceous Basin.

\section{Systematic description}

\section{Order Cyclostomata Busk 1852 \\ Heteroporidae Waters 1880 \\ Tholopora(?) Gregory 1909}

Type species: Ceriopora clavata Goldfuss, 1826, Upper Cretaceous.

\section{Tholopora(?) novaki (Gregory 1909)}

Figs 1-3

1877 Heteropora variabilis d’Orb.; Novák, p. 40 (116), Pl. 9, Figs 10-20

1892 Heteropora variabilis d'Orb.; Počta, p. 25, 33

1909a Domopora novaki Gregory; Gregory, p. 66.

1909b Tholopora novaki (Gregory); Gregory, p. 280.

1984 Heteropora variabilis (d’Orb.); Hradecká, p. 150, P1. III, Fig. 6.

The studied material: 11 zoaria, 19 thin sections.

D i m e n s i o n s: The diameter of colony ranges from 6 to $16 \mathrm{~mm}$, diameter of zoaria groups $30 \times 40 \mathrm{~mm}$, height up to $25 \mathrm{~mm}$;

diameter of short branches: $4.5-25 \mathrm{~mm}$; distance between diaphragms: $0.04-0.18 \mathrm{~mm}$; diameter of zooecial tubes: 0.091-0.197 mm; distance between centres of zooecial tubes: 0.091-0.212 mm; diameter of aperture: $0.060-0.167 \mathrm{~mm}$; diameter of kenozooecia: approximately $0.030-0.045 \mathrm{~mm}$. Values measured in concave places of the same zoarium: diameter of zooecial tubes: $0.091-0.121 \mathrm{~mm}$; diameter of aperture: $0.060-0.091 \mathrm{~mm}$; distance between centres of zooecial tubes: $0.10-0.12 \mathrm{~mm}$.

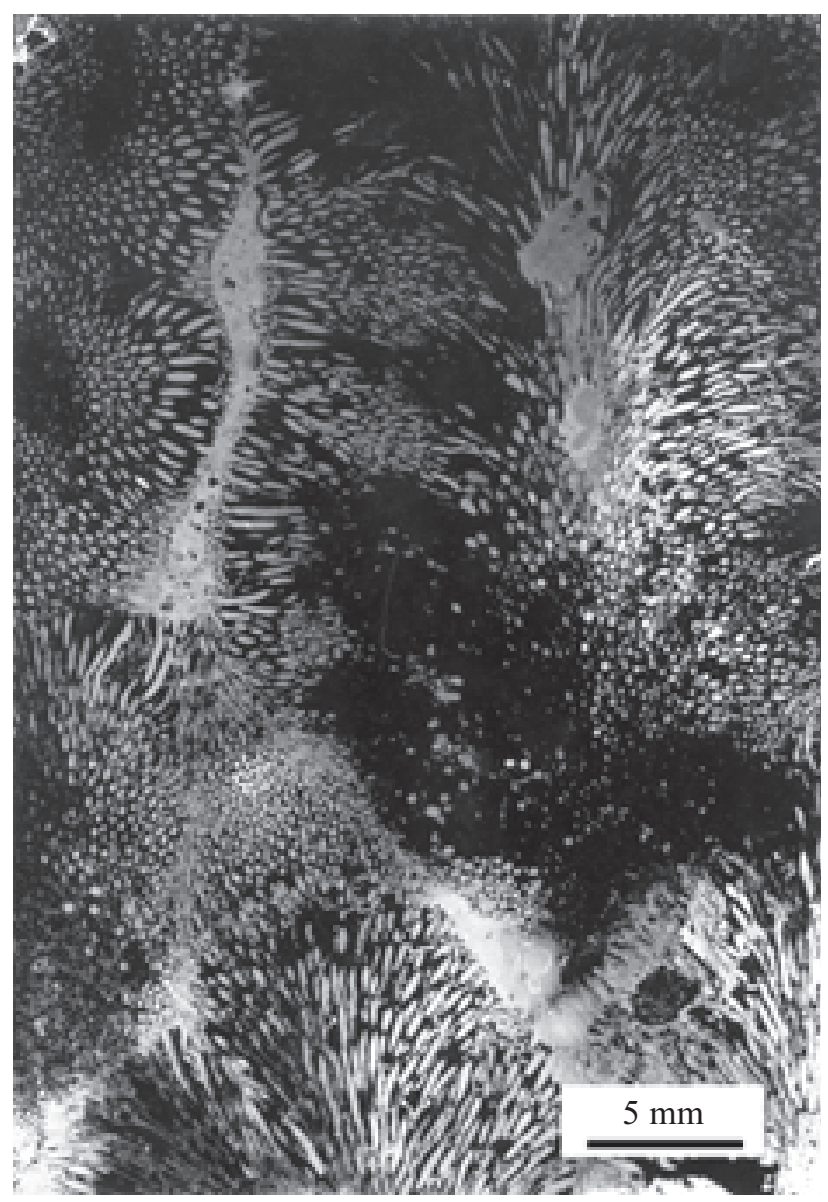

Fig. 1. Tholopora(?) novaki (Gregory 1909). Plaňany, east of Prague. Upper Cenomanian. Longitudinal section through several branches of colony as seen in thin section, showing fan-like pattern of zooecial tubes. Sample HF 2689. 

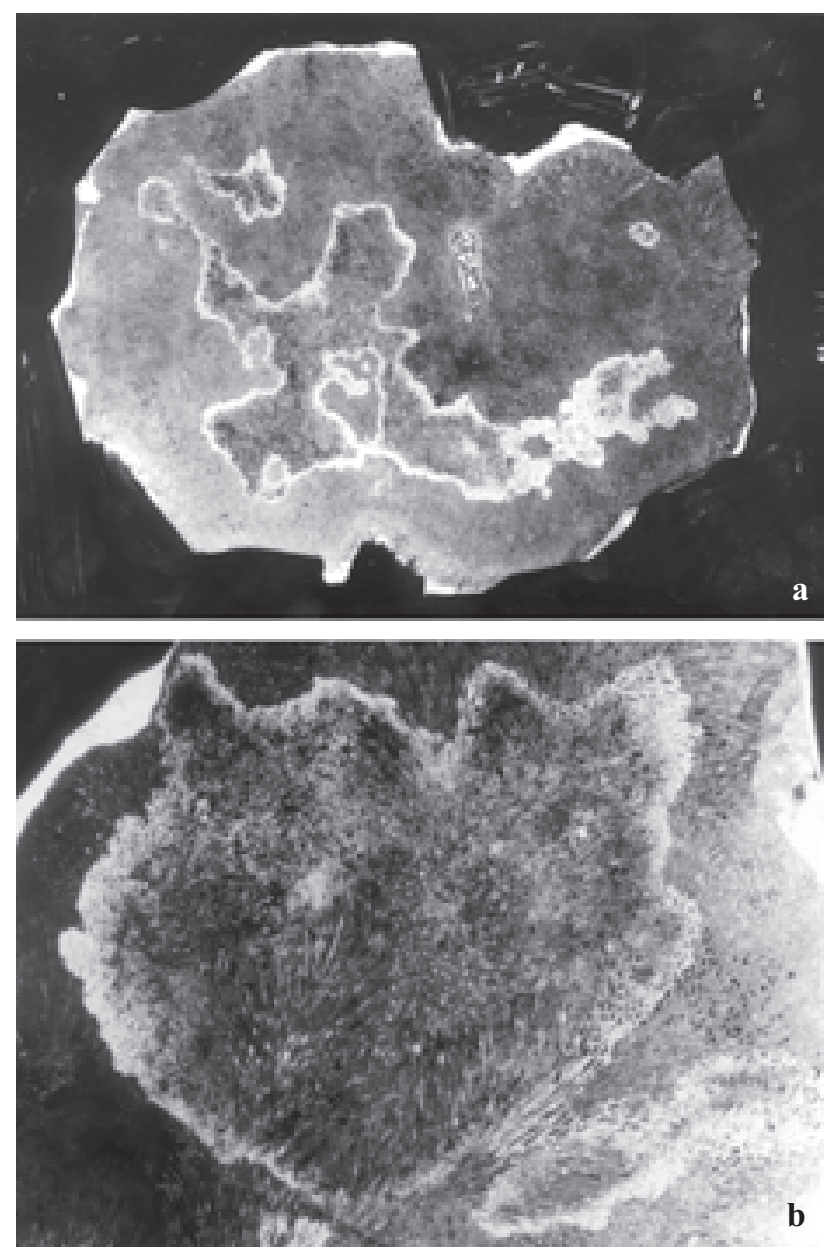

Fig. 2. Tholopora(?) novaki (Gregory 1909). Plaňany, east of Prague. Upper Cenomanian. a - A cross-section through colony, showing radiating pattern of zooecial tubes in branches. The specimen is $28 \mathrm{~mm}$ wide; $b$ - Nearly longitudinal section of the specimen shown in Fig. 2a. The arrangement of zooecial tubes in short vertical rows is visible. In the upper part, diaphragms joint into distinct lines (?).

D e s c ription: The colony is massive at its base, but distally it is narrowing to several short lobate branches. The boundary between individual branches, indicated by a suture, is distinct. Zooecial tubes in a branch show fanlike pattern (Fig. 1). Cross-sections through the lowest parts of branch show a radial pattern of zooecial tubes (Fig. 2a). There are four to six zooecial tubes located in short rows, locally sub-parallel, on sides of colony (Fig. $2 b)$. Zooecial tubes on the top of colony are located in an irregular pattern (Fig. 3). Their contours are in general semi-rounded to polygonal. Closely packed zooecial tubes show better-defined polygonal outlines. The diameter of zooecial tubes is strongly variable - it is much larger in the convex parts of colony and smaller in concave parts, where zooecial tubes are closer packed. Kenozooecia are distributed at random. Diaphragms tend to coalesce in lines sub-parallel with the apical surface of colony (Fig. 2b). The super-imposed layers of colony are better seen on sides of colony in its basal part than in a thin section.

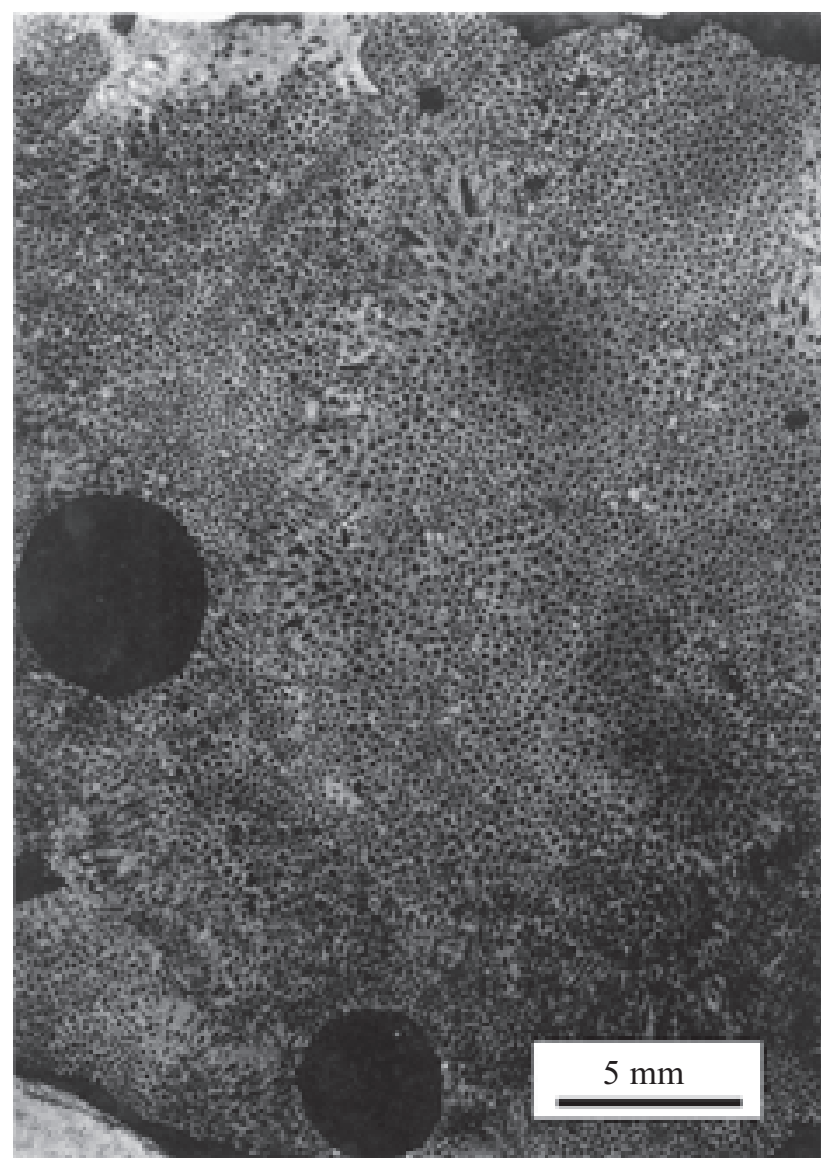

Fig. 3. Tholopora(?) novaki (Gregory 1909). Plaňany, east of Prague. Upper Cenomanian. A transversal section showing irregular pattern of zooecial tubes in the upper part of colony. Sample HF 1436.

N o te s : Gregory 1909b listed the specimens described by Novák (1877) as Heteropora variabilis d'Orbigny into his new genus and proposed for them a new species status of Tholopora novaki (Gregory 1909b). He characterized the genus Tholopora (Gregory 1909a) by the presence of colonies composed of superposed discs arranged in vertical and radiating rows. Homoeomorphic genus Multicrescis d'Orbigny (often mistaken for Heteropora Blainville) differs from Tholopora by irregular distribution of zooecial tubes. Novák (l.c.) mentions the patterns of colony in rows only in juvenile zooids (Novák 1877, P1. 9 - Fig. 17). Gregory (1909b) listed in synonymy of the species Tholopora novaki all the specimens from Bohemia published by Novák (1.c.) and in synonymy of the species Multicrescis variabilis again refers to all the specimens of Novák (1.c.) from Bohemia.

In colonies described below and coming from localities near Prague, that is from the same region as the specimens studied by Novák, zooecial tubes are arranged on sides of colonies in short rows. Also, with Tholopora(?) novaki the zooecial tubes diameter and other dimensions are generally somewhat larger than the corresponding dimensions in Multicrescis variabilis in the original description (d'Orbigny 1852, P1. 800, Figs 3-7). These specimens have been measured by the present author us- 

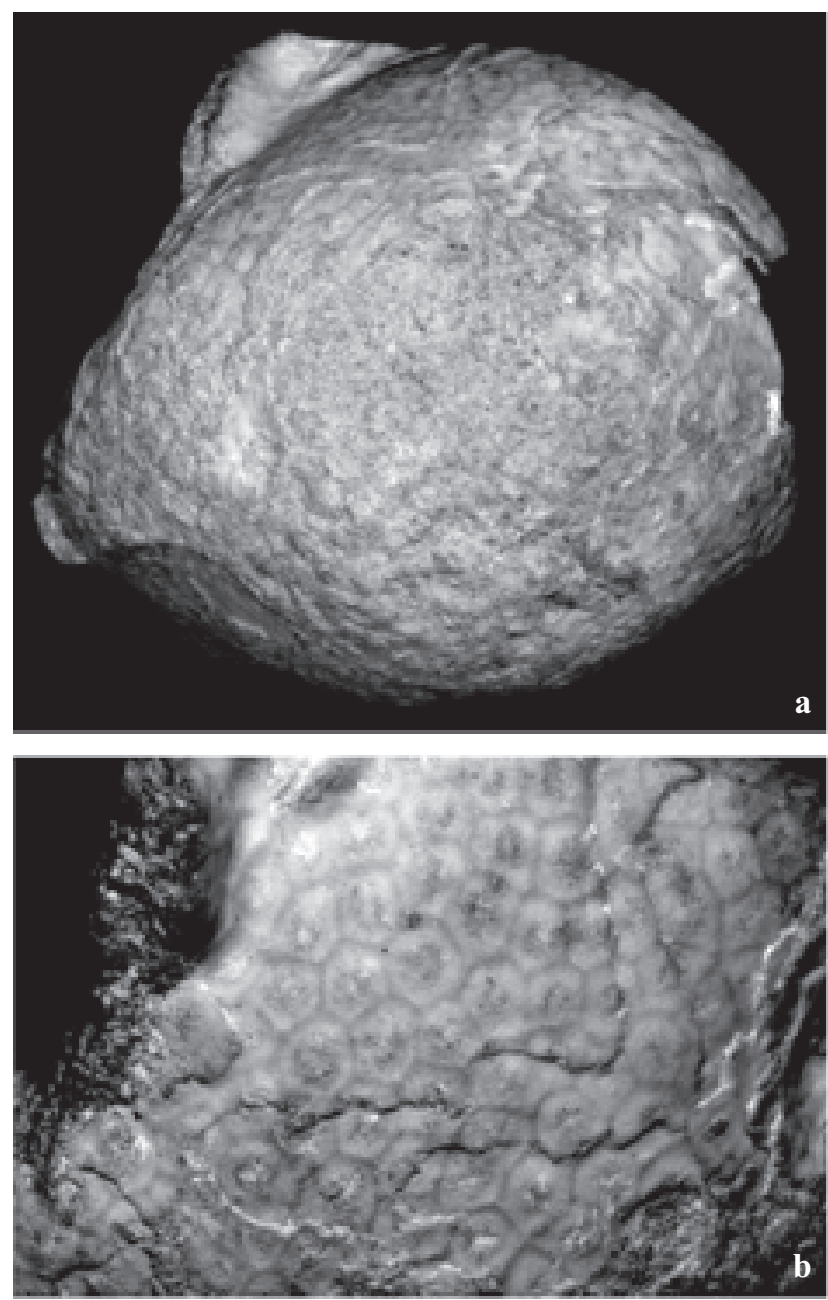

Fig. 4. Radiopora soukupi sp. n. Chotovice near Česká Lípa town. Upper Turonian. Specimen HF 2694. a - A general side view of the colony, $59 \mathrm{~mm}$ wide; $\mathrm{b}$ - Detail from specimen in Fig. 4a, showing polygonal structure of the colony. The area shown is $38 \mathrm{~mm}$ wide; c-Radiopora soukupi sp. n. Chotovice near Česká Lípa town. Upper Turonian. Specimen HF 2694. A cross section showing budding patterns of zooecial tubes; $\mathrm{d}-$ Radiopora soukupi $\mathrm{sp}$. $\mathrm{n}$. Chotovice near Česká Lípa town. Upper Turonian. Specimen HF 2694. Detail from Fig. 4c; e-Radiopora soukupi sp. n. Chotovice near Česká Lípa town. Upper Turonian. Specimen HF 2694. Vertical section of the same specimen as in Fig. $4 c$.

ing thin sections prepared from one of these types (Catalogue No. R 61636, d'Orbigny collection, Muséum national d'histoire naturelle, Paris). The dimensions are as follows: diameter of zooecial tubes $0.075-0.125 \mathrm{~mm}$, diameter of apertures $0.050-0.080 \mathrm{~mm}$, distance of zooecial tubes centers $0.076-0.120 \mathrm{~mm}$. For this reason, the taxonomic classification proposed by Novák (1877) is used in the present description. However, due to uncertain status in systematics, this genus is written as Tholopora(?).

D is tribution: Upper Cenomanian in Bohemia, including localities Kamajka, Kolín, Zbyslav, Plaňany and Netřeba and Lower Turonian of Bohemia (Plaňany).
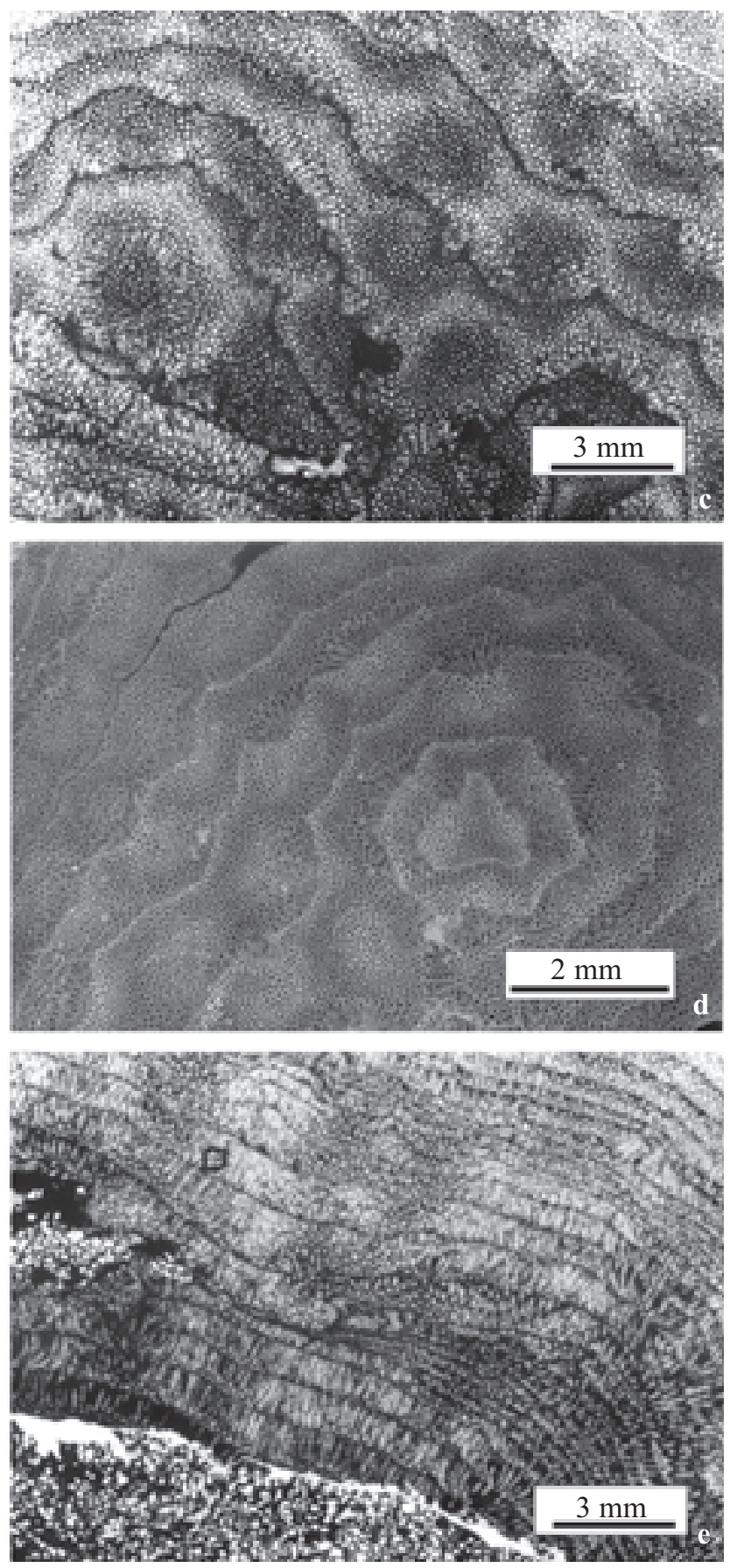

\section{Lichenoporidae Smitt 1867 Radiopora d'Orbigny 1849}

Type species: Ceriopora formosa Michelin 1846

\section{Radiopora soukupi sp. $\mathbf{n}$.}

Figs $4 \mathrm{a}-\mathrm{e}$

Holot y p e : No. HF 2694 and thin sections prepared from this specimen, Nos. 17171/II and 17172/II in the collection of the Czech Geological Survey, Prague. Illustrated in Figs 4a-e.

Ty p i ca 1 be d s: upper part of the Jizera Formation, Upper Turonian. Typical 1 oc ality: Borehole J 48 0751, depth 509 m, Chotovice north of Česká Lípa town, near southern suburbs of the Nový Bor town, north of Prague. 
The name is in honour of Dr. Josef Soukup (1904-1980) for his life-long activities in study of the Cretaceous Basin.

Dimensions: diameter of colony $70 \times 60 \mathrm{~mm}$, height $35 \mathrm{~mm}$; diameter of the radial group (see below) 3-4 mm; width of layer forming colony $=0.25-1.07 \mathrm{~mm}$; diameter of zooecial tubes $=0.136$ $0.198 \mathrm{~mm}$; diameter of aperture $=0.060-0.183$; distance between centres of zooecial tubes $=0.091-0.213 \mathrm{~mm}$; diameter of kenozooecia approximately $0.030-0.045 \mathrm{~mm}$

D e s c ri p t i o n: Massive, hemi-spheroidal colony covered by low monticuli (mamelons in Gegory 1909b), composed of a large number of well-defined superposed layers. With regard to the mode of budding, described for this genus by d'Orbigny 1852, new monticuli appear in sub-concentric belts around a limited number of growth centres. Closely packed rows of zooecial tubes radiate from porous apexes of monticuli. Each of them contains eight to ten apertures in a uniserial row. These rows of zooecial tubes, seemingly closely packed, probably alternate with a narrow zone of kenozooecia. The organization of zooecial tubes in rows becomes indistinct with an increasing distance from monticuli. The set of zooecial tubes arranged around monticuli on a nearly polygonal surface bound by a low ridge represents a basic unit of colony, called radial group by Gregory (1909b) (="sous-colonie" according to d'Orbigny 1852). The contour of zooecial tubes is sub-rounded polygonal and they are of rather uniform appearance. The subhorizontal diaphragms are thin, moderately densely packed. The layers composing the colony are very numerous and distinctly bound. They show a variable thickness and are continuous through whole colony. At the base of each layer of zooecial tubes they diverge laterally from the vertical axis of the monticuli to take a vertical position as they approach the next layer. The layers of zooecial tubes tend to get released as an onion-skin.

N o te s: Radiopora soukupi sp. n. shows a similar shape of colony as the species Radiopora neocomiensis (d'Orbigny 1850). However, according to Gregory (1909b), the latter species is an older synonym for $R a$ diopora heteropora d'Orbigny (1854). The new species differs from it by more numerous radiating rows of zooecial tubes and a larger number of apertures in these rows.
The clearly defined sub-polygonal shape of the basic radiating group in Radiopora soukupi $\mathrm{sp}$. n. reminds illustration of Radiopora bulbosa d'Orb. (in d'Orbigny 1852, P1. 650, Fig. 7), i.e., the species, which Gregory (1909) classified as synonym to Radiopora labyrinthica (Michelin 1846). The newly described species differs from it by the presence of monticuli on the surface of colony and a smaller diameter of zooecial tubes.

D i s tribution: Upper Turonian in Bohemia, locality Chotovice near Česká Lípa town.

Acknowledgements. My thanks go to S. Čech, Czech Geological Survey, Prague, who provided information on the borehole and on stratigraphy of the region. Dr. S. BartaCalmus, Muséum national d'histoire naturelle, Paris, made possible my study of one type of the species Multicrescis variabilis d'Orbigny. Professor N. Vavra from the Palaeontological Institute, Geozentrum in Vienna, commented an early version of this manuscript and provided valuable suggestions. Photographs were prepared by N. Hrdličková, K. Navrátilová, B. Sláma and R. Vodrážka.

Submitted February 3, 2005

\section{References}

Goldfuss, A. (1826-1833): Petrefacta germaniae (1). 252 pp. Düsseldorf. Gregory, J. W. (1909a): New Cretaceous Bryozoa. Geol. Mag. Dec. Vol. VI. London.

- (1909b): Catalogue of the fossil Bryozoa in the Depart. of Geology, British |Museum (Nat. Hist.). The Cretaceous Bryozoa, Vol. II, 1346. London.

Hradecká, L. (1984): Upper Cretaceous Cyclostomate Bryozoa from the locality Zbyslav near Č́slav. Sbor. Geol. Věd, Paleont. 26, 139-156. Praha.

Novák, O. (1877): Beitrag zur Kenntniss der Bryozoen der Böhmischen Kreideformation. Denkschriften (Österr. Akad. Wiss.), math. naturwiss. K1. 37, 79-126. Wien.

Orbigny, A. d'(1850-1852): Paléontologie française. Terrain crétacés, V, Bryozoaires. 1-1192. Paris.

Počta, F. (1892): O mechovkách z korycanských vrstev pod Kaňkem u Kutné Hory (Ueber Bryozoen aus dem Cenoman am Fusse des Gangberges Bei Kuttenberg). Palaeontographica Bohem. 2, 1-46. Praha. (in Czech)

\section{Dva druhy cyklostomátních mechovek ze svrchního cenomanu - turonu české křídové pánve, Česká republika}

V předložené práci jsou popsány dva druhy cyklostomátních mechovek z české křídové pánve: Tholopora(?) novaki (Gregory 1909), druh, který Novák (1877) a Počta (1892) uvedli jako Heteropora variabilis d'Orbigny (1852) (rod Heteropora byl zaměňován s Multicrescis d'Orbigny 1852). Gregory (1909) přeřadil tento druh mechovek ke svému rodu Tholopora a navrhnul pro něj nové druhové jméno Tholopora novaki (Gregory 1909). Radiopora soukupi sp. n. je ojedinělým nálezem z vrtu J 48 O751 u Chotovic na severním okraji České Lípy, blízko j. okraje Nového Boru. Vzorek pochází ze svrchní části jizerského souvrství (svrchní turon). 